\title{
Black soldier fly meal effects on meagre health condition: gut morphology, gut microbiota and humoral immune response
}

\author{
A. Couto ${ }^{1,2, \#, \text { C.R. Serra }}{ }^{1,2, \#}$, I. Guerreiro ${ }^{1}$, F. Coutinho ${ }^{1}$, C. Castro ${ }^{1}$, F. Rangel $^{1,2}$, A.S. Lavrador ${ }^{1}$, M. Monteiro ${ }^{1,2}$, \\ R. Santos ${ }^{1,2}$, H. Peres ${ }^{1,2}$, P. Pousão-Ferreira ${ }^{3}$, L. Gasco ${ }^{4 *}$ iD, F. Gai ${ }^{5}$, A. Oliva-Teles ${ }^{1,2}$ and P. Enes ${ }^{1,2}$ \\ ${ }^{1}$ CIMAR/CIIMAR - Centro Interdisciplinar de Investigação Marinha e Ambiental, Universidade do Porto, Terminal \\ de Cruzeiros do Porto de Leixões, Av. General Norton de Matos s/n, 4450-208 Matosinhos, Portugal; ${ }^{2}$ Departamento \\ de Biologia, Faculdade de Ciências, Universidade do Porto, Rua do Campo Alegre, Ed. FC4, 4169-007 Porto, Portugal; \\ ${ }^{3}$ Instituto Português do Mar e da Atmosfera (IPMA), Estação Piloto de Piscicultura de Olhão, Av. 5 de Outubro s/n, 8700- \\ 305 Olhão, Portugal; ${ }^{4}$ Dipartimento di Scienze Agrarie, Forestali e Alimentari, Università degli Studi di Torino, Largo P. \\ Braccini 2, 10095 Grugliasco, Italy; ${ }^{5}$ Istituto di Scienze delle Produzioni Alimentari, Consiglio Nazionale delle Ricerche, \\ Largo P. Braccini 2, 10095 Grugliasco, Italy; laura.gasco@unito.it; " ${ }^{*}$ these authors contributed equally to the study
}

Received: 3 May 2021 / Accepted: 18 November 2021

(c) 2022 Wageningen Academic Publishers

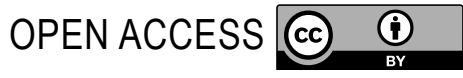

RESEARCH ARTICLE

\begin{abstract}
The effects of black soldier fly (Hermetia illucens) meal (HM) on gut morphology, gut microbial community, and humoral immune response was evaluated in meagre (Argyrosomus regius) juveniles. For that purpose, fish with $18.0 \pm 0.02 \mathrm{~g}$ were fed a control diet (CTR) without HM, and 3 other diets including 10, 20 and 30\% HM (diets HM10, HM20 and HM30, respectively), replacing 17, 35 and 52\% of fish meal (FM), for 9 weeks. The meagre distal intestine (DI) showed no significant histomorphologic alterations in fold height, lamina propria, submucosa width and cellularity, and enterocytes shape, between dietary treatments. Increasing numbers of eosinophilic granulocytes and intraepithelial leukocytes were observed in fish fed the HM30 diet compared to the CTR and HM10 diets. The mean DI score was higher in meagre fed the HM30 diet, denoting increased overall histomorphological alterations in that group compared to fish fed the CTR diet. No differences in gut bacterial profiles (number of operational taxonomic units, microbiota richness, diversity, and similarity indices) were observed between dietary treatments, either in allochthonous (digesta) and autochthonous (mucosa) communities. Plasma anti-protease activity increased with increasing dietary HM level, while no significant differences were observed in the plasmatic protease, peroxidase, lysozyme and bactericidal activities, nitric oxide production and total immunoglobulins. Overall, and in order to avoid gut histomorphological alterations, an inclusion level up to 10\% of HM, corresponding to 17\% of FM replacement, is recommended for meagre juveniles.
\end{abstract}

Keywords: Argyrosomus regius, gut bacteria, gut histology, Hermetia illucens, immune status

\section{Introduction}

Insects are considered a promising protein source in aquaculture, with the potential to be used as an alternative to fish meal (FM) and plant feedstuffs, due to their high nutritional value and environmentally friendly production (Gasco et al., 2020a,b; Nogales-Mérida et al., 2019). The European Commission issued Regulation No. 2017/893, effective from July 2017, allowed the use of processed animal protein derived from seven insect species in aquafeeds, thus boosting insect market development and competitiveness in this region. Black soldier fly (Hermetia illucens, HI), one of the seven authorised insect species in Europe, is among the most farmed insects in the world. HI can be easily reared in mass cultures on almost all organic wastes, being very efficient at bioconverting poor substrates into valuable larval biomass to be used as an animal feed ingredient (Hawkey et al., 2021; Ravi et al., 2020). HI larvae have high protein content (31-59\% dry matter (DM)), with a balanced essential amino acid profile, close to that of FM (Nogales- 
Mérida et al., 2019). Its lipid content range from 11-41\% DM, depending on processing, and fatty acid profile can be modulated by diet to meet fish needs (Hawkey et al., 2021; Nogales-Mérida et al., 2019).

Despite the high nutritional value of Hermetia ilucens meal (HM), its potential as FM replacement for marine fish has been scarcely studied (Abdel-Tawwab et al., 2020; Belghit et al., 2018, 2019; Guerreiro et al., 2020, 2021; Karapanagiotidis et al., 2014; Kroeckel et al., 2012; Lock et al., 2016; Magalhães et al., 2017; Mastoraki et al., 2020; Wang et al., 2019). In some species, like European seabass (Dicentrarchus labrax) and Atlantic salmon (Salmo salar), HM inclusion levels up to 20 and 25\%, respectively did not affect fish growth performance (Abdel-Tawwab et al., 2020; Belghit et al., 2019; Lock et al., 2016; Magalhães et al., 2017; Mastoraki et al., 2020). On the contrary, in gilthead seabream (Sparus aurata) and turbot (Psetta maxima), HM inclusion levels of 10 and $17 \%$, respectively depressed fish growth (Karapanagiotidis et al., 2014; Kroeckel et al., 2012). Zootechnical performance of meagre (Argyrosomus regius) from the present study, showed that $10 \%$ HM can be included in the diets with no adverse effect on growth and digestibility (Guerreiro et al., 2020, 2021).

Insects are also sources of compounds such as chitin, silkrose and dipterose, which may exert positive effects on the fish immune system, hence improving health status and decreasing disease susceptibility (Gasco et al., 2018, 2020c). Until now, only few studies addressed the effect of HM in fish immune system (Abdel-Latif et al., 2021; Cardinaletti et al., 2019; Chaklader et al., 2019; Li et al., 2019; Stenberg et al., 2019; Wang et al., 2019; Xiao et al., 2018; Zarantoniello et al., 2018), with the majority reporting positive effects. Thus, a tendency for increased lysozyme and phagocytosis activities was observed in yellow catfish (Pelteobagrus fulvidraco) fed diets with 6 and 11\% HM inclusion levels (Xiao et al., 2018). In barramundi (Lates calcarifer), a $45 \%$ poultry by-product meal diet supplemented with 10\% HM enhanced fish survival against Vibrio harveyi, increased serum immune response and head kidney immune-related genes expression, 24 hours after the challenge (Chaklader et al., 2019). The inclusion of $60 \% \mathrm{HM}$ in diets for Atlantic salmon increased the transcription levels of $\operatorname{cd} 3 \gamma \delta$ and foxp3 in the proximal and distal intestine, suggesting that HM was capable of stimulating regulatory $\mathrm{T}$-cell activity in the intestine $(\mathrm{Li}$ et al., 2019). A 21\% HM dietary inclusion level led to an up-regulation of pro-inflammatory cytokines in zebrafish (Danio rerio), and pro- and anti-inflammatory cytokines in the medium gut of rainbow trout (Oncorhynchus mykiss) (Cardinaletti et al., 2019; Zarantoniello et al., 2018).

As gut is the main site of nutrient digestion and absorption, intestinal health is critical for dietary nutrients utilisation and fish growth. Therefore, gut morphological changes must be considered when new ingredients are under evaluation.

Studies addressing the effect of insect meals on fish gut morphology showed that dietary inclusion of HM up to 19\% (Japanese sea bass Lateolabrax japonicus) or 40\% (rainbow trout; Siberian sturgeon Acipenser baerii) did not cause negative effects on fish gut morphology (Caimi et al., 2020; Józefiak et al., 2019a; Renna et al., 2017; Wang et al., 2019). In contrast, in clownfish (Amphiprion ocellaris) a 40 and $60 \%$ dietary HM inclusion levels led to a reduction in fold length (Vargas-Abúndez et al., 2019). A positive effect of $\mathrm{HM}$ on villi and enterocyte width, microvilli height and acidic mucins was reported in barramundi fed a $45 \%$ poultry by-product meal diet supplemented with $10 \% \mathrm{HM}$ (Chaklader et al., 2019). In Atlantic salmon, a diet with 15\% HM led to beneficial effects on the fish gut, by reducing enterocyte hyper-vacuolisation in the proximal gut ( $\mathrm{Li}$ et al., 2020).

Fish gut microbial communities respond to a wide range of factors and are closely correlated to the host diet (Egerton et al., 2018), playing a central role in digestion and maintenance of host health (Llewellyn et al., 2014). Insect meals have been shown to positively affect fish gut microbiota biodiversity, regardless of insects' life-cycle stage, defatting process, percentage of dietary inclusion, or fish species (Antonopoulou et al., 2019; Bruni et al., 2018; Huyben et al., 2019; Józefiak et al., 2019a,b; Rimoldi et al., 2019, 2021; Terova et al., 2019). Overall, HM promoted gut bacterial diversity and induced a shift of microbiota towards beneficial bacteria (lactate- and butyrate-producers) at the expense of pathogenic bacteria (Bruni et al., 2018; Huyben et al., 2019; Józefiak et al., 2019b; Rimoldi et al., 2019, 2021; Terova et al., 2019). The positive effects of insect meals on fish gut microbiota have been mainly attributed to chitin, which is a substrate for lactic acid bacteria growth (Ringø et al., 2012), showing also antimicrobial and bacteriostatic properties against harmful Gram-negative bacteria (Nawaz et al., 2018).

This study aimed to evaluate the effect of the dietary replacement of FM by HM on the gut morphology, gut microbiota and humoral immune response of meagre juveniles, a novel species for Mediterranean aquaculture diversification.

\section{Material and methods}

\section{Experimental diets and trial}

Four isoproteic (50\%) and isolipidic (19\%) diets were formulated. A FM-based diet was used as control (CTR diet), and three other diets were formulated to include 10 , 
20 and $30 \%$ of partially defatted HM (diets HM10, HM20 and HM30, respectively), replacing 17, 35 and 52\% of FM, respectively. The HM utilised in this study was provided by a European insect company and the larvae used to obtain the HM had been raised on plant by-products and partially defatted with a mechanical process performed using high pressure and without solvents. No other information on substrate or processing methodologies was provided by the producer as they are considered confidential. All dietary ingredients were finely ground, well mixed, and dry pelleted in a laboratory pellet mill (California Pellet Mill, CPM Crawfordsville, IN, USA) through a $2 \mathrm{~mm}$ die. The pellets were then dried in an oven at $40{ }^{\circ} \mathrm{C}$ for 24 hours and stored at $-20^{\circ} \mathrm{C}$ in airtight bags until used. Ingredients and proximate composition of the experimental diets are presented in Table 1 (previously published in Guerreiro et al. (2020)). Diets and HM amino acid and fatty acid composition are presented in Guerreiro et al. (2020).

Table 1. Ingredient composition and proximate analysis of the experimental diets. ${ }^{1}$

\begin{tabular}{|c|c|c|c|c|}
\hline & \multicolumn{4}{|l|}{ Diets } \\
\hline & CTR & HM10 & HM2O & HM30 \\
\hline \multicolumn{5}{|l|}{ Ingredients (\% dry weight basis) } \\
\hline Fish meal ${ }^{2}$ & 40.0 & 33.1 & 26.1 & 19.2 \\
\hline Soluble fish protein concentrate ${ }^{3}$ & 2.5 & 2.5 & 2.5 & 2.5 \\
\hline Hermetia illucens ${ }^{4}$ & - & 10.0 & 20.0 & 30.0 \\
\hline Wheat gluten ${ }^{5}$ & 5.0 & 5.0 & 5.0 & 5.0 \\
\hline Corn gluten ${ }^{6}$ & 7.5 & 7.5 & 7.5 & 7.5 \\
\hline Soybean meal ${ }^{7}$ & 14.0 & 14.0 & 14.0 & 14.0 \\
\hline Wheat meal ${ }^{8}$ & 15.0 & 11.8 & 8.5 & 5.2 \\
\hline Fish oil & 12.3 & 12.1 & 11.8 & 11.6 \\
\hline Vitamin premix ${ }^{9}$ & 1.0 & 1.0 & 1.0 & 1.0 \\
\hline Mineral premix ${ }^{10}$ & 1.0 & 1.0 & 1.0 & 1.0 \\
\hline Choline chloride (50\%) & 0.5 & 0.5 & 0.5 & 0.5 \\
\hline Binder ${ }^{11}$ & 1.0 & 1.0 & 1.0 & 1.0 \\
\hline Taurine $^{12}$ & 0.2 & 0.2 & 0.2 & 0.2 \\
\hline Dibasic calcium phosphate & - & 0.4 & 0.8 & 1.3 \\
\hline \multicolumn{5}{|l|}{ Proximate analyses (\% dry weight basis) } \\
\hline Dry matter & 93.7 & 94.1 & 95.4 & 94.9 \\
\hline Crude protein & 50.3 & 49.3 & 50.6 & 50.1 \\
\hline Crude fat & 19.0 & 18.6 & 18.9 & 18.1 \\
\hline Ash & 9.2 & 9.7 & 10.2 & 10.6 \\
\hline Energy $(\mathrm{kJ} / \mathrm{g})$ & 23.1 & 22.8 & 22.9 & 22.8 \\
\hline Chitin & 0.0 & 0.6 & 1.1 & 1.6 \\
\hline \multicolumn{5}{|c|}{${ }^{1} \mathrm{CP}=$ crude protein; $\mathrm{DM}=$ dry matter; $\mathrm{GL}=$ gross lipid. } \\
\hline \multicolumn{5}{|c|}{${ }^{2}$ Steam Dried LT-FM, Copicesa S. A., Spain (CP: 73.2\% DM; GL: 11.4\% DM). } \\
\hline \multicolumn{5}{|c|}{${ }^{3}$ Sopropèche G, France (CP: $77.0 \%$ DM; GL: 18.4\% DM). } \\
\hline \multicolumn{5}{|c|}{${ }^{4}$ Black soldier fly larvae meal (CP: $55.4 \%$ DM; GL: $10.9 \%$ DM; ash: 1.3\% DM; chitin 5.5\% DM). } \\
\hline \multicolumn{5}{|c|}{${ }^{5}$ Sorgal, S.A. Ovar, Portugal (CP: 83.1\% DM; GL: 1.9\% DM). } \\
\hline \multicolumn{5}{|c|}{${ }^{6}$ Sorgal, S.A. Ovar, Portugal (CP: $70.2 \%$ DM; GL: 2.3\% DM). } \\
\hline \multicolumn{5}{|c|}{${ }^{7}$ Sorgal, S.A. Ovar, Portugal (CP: 50.6\% DM; GL: 1.6\% DM). } \\
\hline \multicolumn{5}{|c|}{${ }^{8}$ Sorgal, S.A. Ovar, Portugal (CP: 14.3\% DM; GL: 2.0\% DM). } \\
\hline \multicolumn{5}{|c|}{$\begin{array}{l}{ }^{9} \text { Vitamins (mg/kg diet): retinol, } 18,000 \text { (IU/kg diet); cholecalciferol, 2,000 (IU/kg diet); a-tocopherol, 35; menadione sodium bisulphate, 10; thiamine, 15; riboflavin, } \\
\text { 25; Ca pantothenate, 50; nicotinic acid, 200; pyridoxine, 5; folic acid, 10; cyanocobalamin, 0.02; biotin, 1.5; ascorbyl monophosphate, 50; inositol, 400. }\end{array}$} \\
\hline \multicolumn{5}{|c|}{$\begin{array}{l}{ }^{10} \text { Minerals (mg/kg diet): cobalt sulphate, 1.91; copper sulphate, 19.6; iron sulphate, 200; sodium fluoride, 2.21; potassium iodide, } 0.78 \text {; magnesium oxide, } 830 \text {; } \\
\text { manganese oxide, 26; sodium selenite, 0.66; zinc oxide, 37.5; dibasic calcium phosphate, } 5.93 \text { (g/kg diet); potassium chloride, } 1.15 \text { (g/kg diet); sodium chloride, } \\
0.44 \text { (g/kg diet). }\end{array}$} \\
\hline \multicolumn{5}{|l|}{${ }^{11}$ Aquacube. Agil, UK. } \\
\hline Fend areda tourine & & & & \\
\hline
\end{tabular}


The growth trial was performed with meagre (A. regius) juveniles and is described in detail in Guerreiro et al. (2020). Shortly, the experimental diets were randomly assigned to triplicate tanks, 12 tanks in total, each tank with 18 fish with an initial mean body weight of $18.0 \pm 0.02 \mathrm{~g}$. The trial was conducted in a recirculating aquaculture system thermo-regulated to $22.4 \pm 0.6^{\circ} \mathrm{C}$ and lasted 9 weeks. During that period, fish were hand-fed twice a day, 6 days per week, until visual satiation. The experiment was performed by accredited scientists (following FELASA category C recommendations) and approved by the General Directorate of Food and Veterinary from Portugal (Certification number ORBEA-CIIMAR 30-2019), according to the European Union directive 2010/63/EU on the protection of animals for scientific purposes.

\section{Sampling}

At the end of the trial, 5 fish from each tank were randomly sampled 5 hours after the morning meal to assure the presence of digesta in the gut. Blood from 3 fish was collected from the caudal vein with a heparinised syringe, placed in heparinised tubes and centrifuged at 10,000 $\times g$ for 10 minutes at room temperature. Plasma aliquots were stored at $-80^{\circ} \mathrm{C}$, until humoral immune parameters analysis. Fish were then sacrificed with a sharp blow to the head and dissected on chilled trays. The digestive tract was freed from adjacent adipose and connective tissues. Circa $1 \mathrm{~cm}$ of the distal intestine (DI; distinguished from the mid intestine by an enlarged diameter and darker mucosa) was sampled for histological evaluation. The samples were properly washed in phosphate-buffered saline, carefully blotted dry with a paper towel, immediately fixed in phosphate-buffered formalin (4\%, pH 7.4) for 24 hours, and subsequently transferred to ethanol at $70 \%$ until further processing. The remaining 2 fish from each tank were sampled under aseptic conditions for allochthonous (digesta) and autochthonous (mucosa) microbiota characterisation. Digesta samples were collected by squeezing the entire gut, while mucosa samples were obtained by scraping the internal gut mucosal surface. Samples were immediately frozen in liquid nitrogen and stored at $-80^{\circ} \mathrm{C}$ until microbiota diversity analysis.

\section{Histological processing and morphological evaluation}

Three DI samples per tank $(n=9)$ were processed and sectioned using standard histological techniques. Sections were stained with haematoxylin and eosin and evaluated according to Couto et al. (2016). Briefly, a semi-quantitative scoring system with the range of tissue scores set from 1 (normal) to 5 (highly modified) was used to evaluate the extent of structure alterations: widening and shortening of the intestinal folds, widening of the lamina propria and submucosa, infiltration of a mixed leucocyte population in the lamina propria and submucosa, and alterations in enterocytes architecture including supranuclear vacuolisation. The overall value of histomorphological alterations was calculated by averaging scores of the individual parameters described above. Slides were blindly evaluated by light microscopy (Primo Star, Zeiss, Oberkochen, Germany) and images were acquired with Zen software (Blue edition, Zeiss).

\section{Microbial diversity}

Gut microbiota composition was assessed in pooled samples of 2 fish per tank to reduce variability $(n=3)$. Bacterial genomic DNA was extracted from $300 \mathrm{mg}$ of digesta and mucosa, following the procedure described in Serra et al. (2021). Bacterial 16S rRNA gene fragments were amplified by a touchdown PCR on a T100 ${ }^{\mathrm{TM}}$ Thermal Cycler (Bio-Rad Laboratories Lda., Amadora, Portugal), using oligonucleotide primers 16S-358F (which has a GC clamp at the $5^{\prime}$ end) and 16S-517R (Muyzer et al., 1993).

16SrRNA genes polymorphisms were analysed by denaturing gradient gel electrophoresis (DGGE). For that purpose, $300 \mathrm{ng}$ of each PCR product were loaded on the $8 \%$ acrylamide gel, prepared with a denaturing gradient of $30-70 \% 7 \mathrm{M}$ urea/40\% formamide. Electrophoresis was performed on a DCode ${ }^{\mathrm{mix}}$ Universal Mutation Detection System (Bio-Rad Laboratories Lda.), for 16 hours at $60{ }^{\circ} \mathrm{C}$, $65 \mathrm{~V}$ in 1xTAE buffer. Following 1 hour staining in $200 \mathrm{ml}$ of 1XTAE buffer containing SYBR Gold Nucleic Acid Gel Stain (Sigma-Aldrich, Química, S.L., Sintra, Portugal), DGGE gels were imaged on a Gel Doc EZ System (Bio-Rad Laboratories Lda.).

Distinct bands were excised from the gel, eluted in 20 $\mathrm{ml}$ ultrapure water, and re-amplified using the same oligonucleotide primers as above, but without the GC clamp. Amplicons were sequenced (STAB VIDA, Lisboa, Portugal) and phylogenetically analysed, by comparing with the GenBank non-redundant nucleotide database using BLAST (http://www.ncbi.nlm.nih.gov), to identify the closest known species. Only sequences higher than 100 bp reads and $80-100 \%$ query coverage were considered valid identification.

\section{Humoral immune parameters}

Plasma anti-protease, peroxidase and lysozyme activities, nitric oxide and total immunoglobulins were determined as described in Guardiola et al. (2018).

\section{Bactericidal activity}

Bactericidal activity was performed using V. anguillarum DSMZ 21597. Bacteria were grown in brain heart infusion (BHI) for 24 hours at $25^{\circ} \mathrm{C}$, and cultures centrifuged at $4,000 \times g$ for 15 minutes at room-temperature. Bacterial cells were resuspended in sterile BHI medium to a final 
concentration of $1 \times 10^{7}$ colony-forming units (cfus) $/ \mathrm{ml}$. Inoculum concentration was confirmed by plating serial dilutions of bacterial suspensions. Bactericidal activity was then determined in plasma samples following the method of Graham et al. (1988) with slight modifications. Briefly, $20 \mu \mathrm{l}$ of plasma was added to duplicate wells of a U-shaped 96-well plate. Sterile Hank's balanced salt solution was added to some wells instead of plasma and served as a positive control. To each well, $20 \mu \mathrm{l}$ of $\mathrm{V}$. anguillarum DSMZ $21597\left(1 \times 10^{7} \mathrm{cfu} / \mathrm{ml}\right)$ were added and the plate was incubated for 2.5 hours at $25^{\circ} \mathrm{C}$. To each well, $25 \mu \mathrm{l}$ of iodonitrotetrazolium chloride $(1 \mathrm{mg} / \mathrm{ml}$, Sigma-Aldrich, Química, S.L., Sintra, Portugal) were added and incubated for 10 minutes at $25^{\circ} \mathrm{C}$ to allow the formation of formazan. Plates were then centrifuged at $2,000 \times g$ for 10 minutes and the precipitate was dissolved in $200 \mu \mathrm{l}$ of dimethyl sulfoxide (Sigma-Aldrich, Química, S.L.). The absorbance of the dissolved formazan was measured at $490 \mathrm{~nm}$. Total bactericidal activity is expressed as the percentage of killed bacteria, calculated from the difference between the samples and the positive control (100\% living bacteria).

\section{Protease activity}

Protease activity was quantified using the azocasein hydrolysis assay according to the method of Ross et al. (2000). Briefly, $10 \mu \mathrm{l}$ of plasma was incubated with $10 \mu \mathrm{l}$ of phosphate buffer (115 mM NaH$\left.{ }_{2} \mathrm{PO}_{4}, \mathrm{pH} 7.0\right), 100 \mu \mathrm{l}$ of sodium bicarbonate $\left(60 \mathrm{mM} \mathrm{NaHCO}_{3}, \mathrm{pH} 8.3\right)$ and $125 \mu \mathrm{l}$ of $2 \%$ azocasein for 24 hours, with continuous shaking, at room temperature. The reaction was stopped by adding $250 \mu \mathrm{l}$ of $10 \%$ trichloroacetic acid. Following centrifugation $(10,000 \times g, 5 \mathrm{~min}), 100 \mu \mathrm{l}$ of the supernatants were transferred to a 96-well plate in triplicate and $100 \mu \mathrm{l}$ of $1 \mathrm{M} \mathrm{NaOH}$ were added to each well. The optical density was measured at $450 \mathrm{~nm}$. Plasma samples were replaced by trypsin (5 mg/ml, Sigma-Aldrich, Química, S.L.), as positive control (100\% of protease activity), or by phosphate buffer, as negative control ( $0 \%$ activity).

\section{Statistical analysis}

Data are presented as means \pm standard deviation. Statistical analysis was done using SPSS 24.0 software package for Windows (IBM ${ }^{\bullet}$ SPSS $^{\bullet}$ Statistics, New York, NY, USA). Data were checked for normal distribution and homogeneity of variances, normalised when appropriate, and analysed by one-way ANOVA. A polynomial contrasts analysis was performed to determine whether the data followed a linear or quadratic response to dietary HM inclusion. A significant level of 0.05 was used for rejection of the null hypothesis. To illustrate the magnitude of the differences between means, Tukey's multiple range test was performed after ANOVA analysis, when $P<0.05$.
DGGE bands intensity was measured using Quantity One 1-D Analysis Software v4.6.9 (Bio-Rad Laboratories, Lda.) and converted into presence/absence matrices. Relative similarities between dietary treatments and replicates were calculated using Primer software v7.0.5 (PRIMER-E Ltd, Ivybridge, UK). Multivariate non-metric multidimensional scaling (nMDS) was based on Bray-Curtis similarities between relative band abundances. nMDS data representation was considered reliable considering the calculated Kruskal stress value $(<0.2)$ (Clarke and Warwick, 2001). Similarity percentages (SIMPER) were used to represent the relative similarities between dietary treatments. Species richness and diversity were assessed by the Margalef's and the Shannon-Weaver indexes, respectively. DGGE patterns were clustered in dendrograms using the Unweighted Pair Groups Method with Arithmetic Averages (UPGMA).

Histological data were neither normal nor homogeneous and could not be normalised; thus, Kruskal-Wallis nonparametric tests and subsequent pairwise comparisons were performed. The probability level of 0.05 was used for rejection of the null hypothesis in all tests.

\section{Results}

\section{Gut morphology}

Histological evaluation of the DI of meagre showed normal fold height and normal lamina propria and submucosa width and cellularity, independently of diet composition (Table 2). Eosinophilic granulocytes and intraepithelial leukocytes numbers increased with dietary HM inclusion levels, being significantly higher in fish fed the HM30 diet compared to the CTR and HM10 diets (Table 2; Figure 1). Mean score of all evaluated parameters also increased with dietary HM inclusion levels, being significantly higher in fish fed the HM30 diet compared to the CTR diet.

\section{Microbial diversity}

The Bray-Curtis dendrogram (Figure 2) based on the DGGE polymorphic analysis of the gut microbial communities, revealed that allochthonous populations had lower similarity $(<50 \%)$ than autochthonous populations $(\sim 55 \%)$.

Both in allochthonous and autochthonous communities, clustering was only observed for HM20 (75\% similarity) and HM10 diets (85\% similarity), respectively. These results were further elucidated by the nMDS plot of the presence and abundance of DGGE bands (Figure 3) that showed proximity between HM10 and HM20 groups in digesta samples, and between CTR and HM10 groups in the mucosa samples, despite all replicates (except one of CTR group) exhibited 60\% similarity at the mucosal level. 
Table 2. Evaluation of histological alterations in the distal intestine of meagre fed the control (CTR) and the Hermetia illucens meal (HM) diets. ${ }^{1}$

\begin{tabular}{|c|c|c|c|c|c|}
\hline & \multicolumn{4}{|l|}{ Diets } & \multirow{2}{*}{$\begin{array}{l}\text { Kruskal-Wallis } \\
P \text {-value }\end{array}$} \\
\hline & CTR & HM10 & HM2O & HM30 & \\
\hline Mucosal folds height & $1.4 \pm 0.5$ & $1.4 \pm 0.5$ & $1.4 \pm 0.5$ & $1.4 \pm 0.5$ & 1.000 \\
\hline Lamina propria $^{2}$ & $1.8 \pm 0.5$ & $1.9 \pm 0.5$ & $2.7 \pm 0.7$ & $2.5 \pm 1.7$ & 0.171 \\
\hline Submucosa ${ }^{3}$ & $1.6 \pm 0.2$ & $1.8 \pm 0.4$ & $2.5 \pm 0.9$ & $2.1 \pm 0.8$ & 0.385 \\
\hline $\mathrm{EGCs}^{4}$ & $1.4 \pm 0.5^{\mathrm{a}}$ & $1.9 \pm 0.4^{\mathrm{a}}$ & $2.2 \pm 0.5^{\mathrm{ab}}$ & $3.0 \pm 0.0^{\mathrm{b}}$ & 0.009 \\
\hline IELs ${ }^{5}$ & $1.1 \pm 0.2^{\mathrm{a}}$ & $1.3 \pm 0.3^{\mathrm{a}}$ & $1.7 \pm 0.0^{\mathrm{ab}}$ & $2.4 \pm 0.5^{b}$ & 0.004 \\
\hline Enterocytes $^{6}$ & $1.3 \pm 0.5$ & $1.8 \pm 0.1$ & $2.2 \pm 1.0$ & $2.1 \pm 0.6$ & 0.350 \\
\hline Mean score ${ }^{7}$ & $1.4 \pm 0.2^{\mathrm{a}}$ & $1.7 \pm 0.0^{\mathrm{ab}}$ & $2.1 \pm 0.4^{\mathrm{ab}}$ & $2.3 \pm 0.3^{b}$ & 0.021 \\
\hline
\end{tabular}

${ }^{1}$ Scores from 1 to 5 , with 5 indicating major alterations.

2 Width and cellularity of the lamina propria.

${ }^{3}$ Width and cellularity of the submucosa.

${ }^{4} \mathrm{EGC}=$ number of eosinophilic granular cells.

${ }^{5} \mathrm{IEL}=$ number of intraepithelial leucocytes.

${ }^{6}$ Enterocytes shape, nucleus position and vacuolisation.

${ }^{7}$ Mean scores $=$ average scores of the parameters evaluated $(n=3)$.

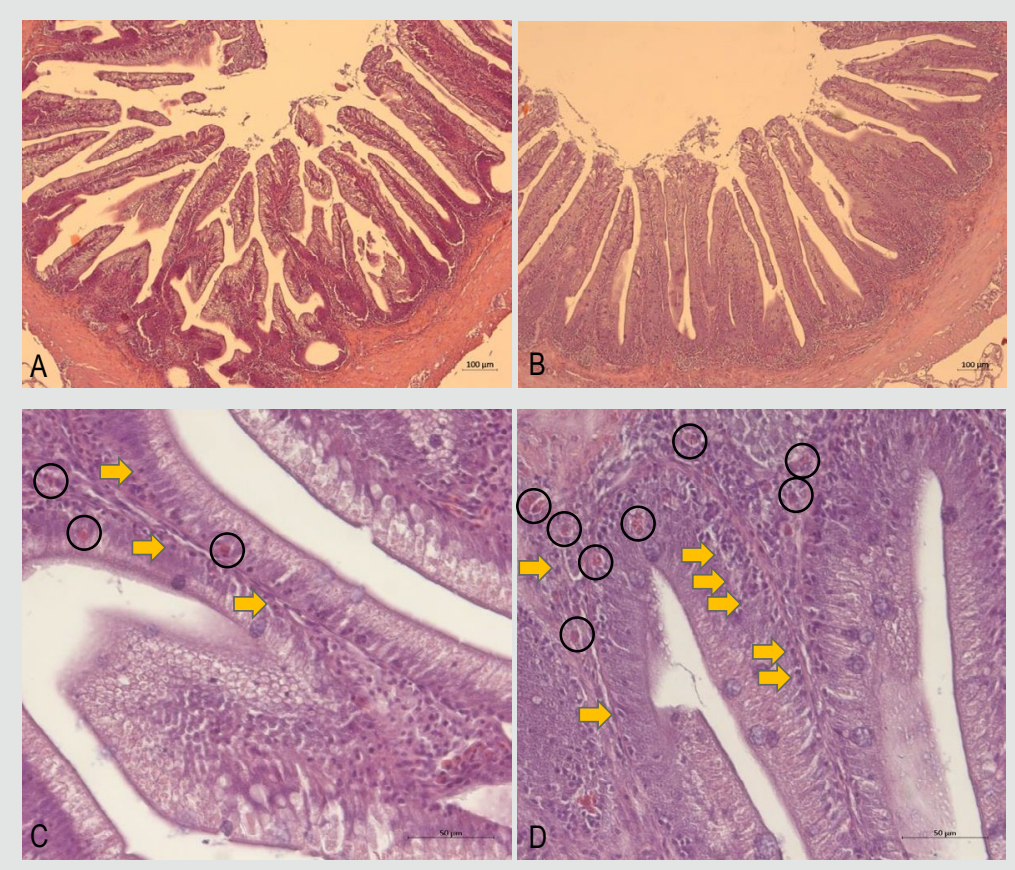

Figure 1. Histomorphological appearance of meagre distal intestine fed the control diet (A, C) or Hermetia illucens meal $30 \%$ diet (B, D). Black circles: eosinophilic granulocytes; yellow arrows: intraepithelial leukocytes; H-E staining. 


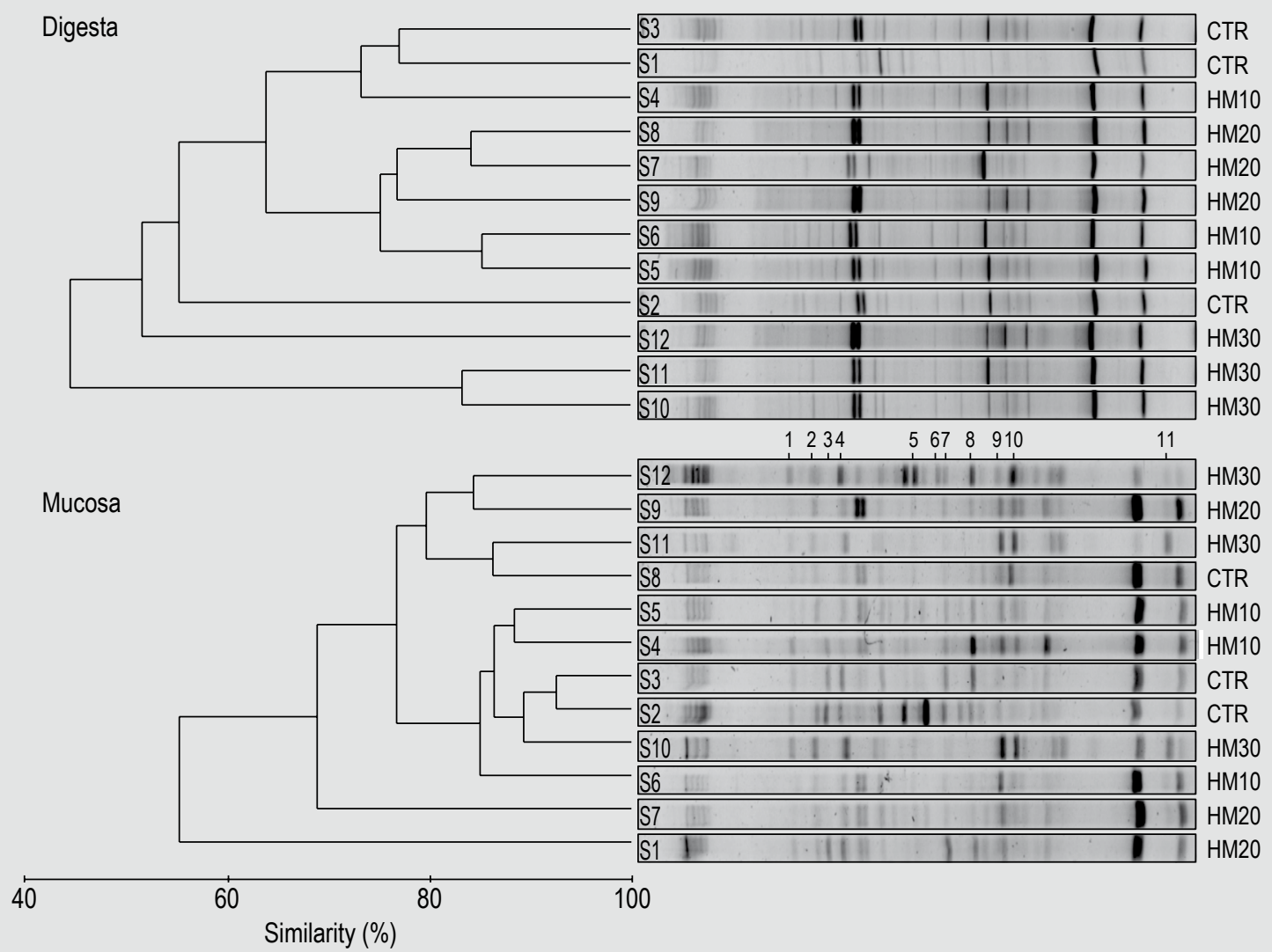

Figure 2. Dendrogram and PCR-DGGE fingerprints of the allochthonous (digesta) and autochthonous (mucosa) gut microbiota of meagre fed the control (CTR) and the Hermetia illucens meal (HM) diets. Numbers on top of mucosa dendrogram indicate bands excised for sequence analysis.

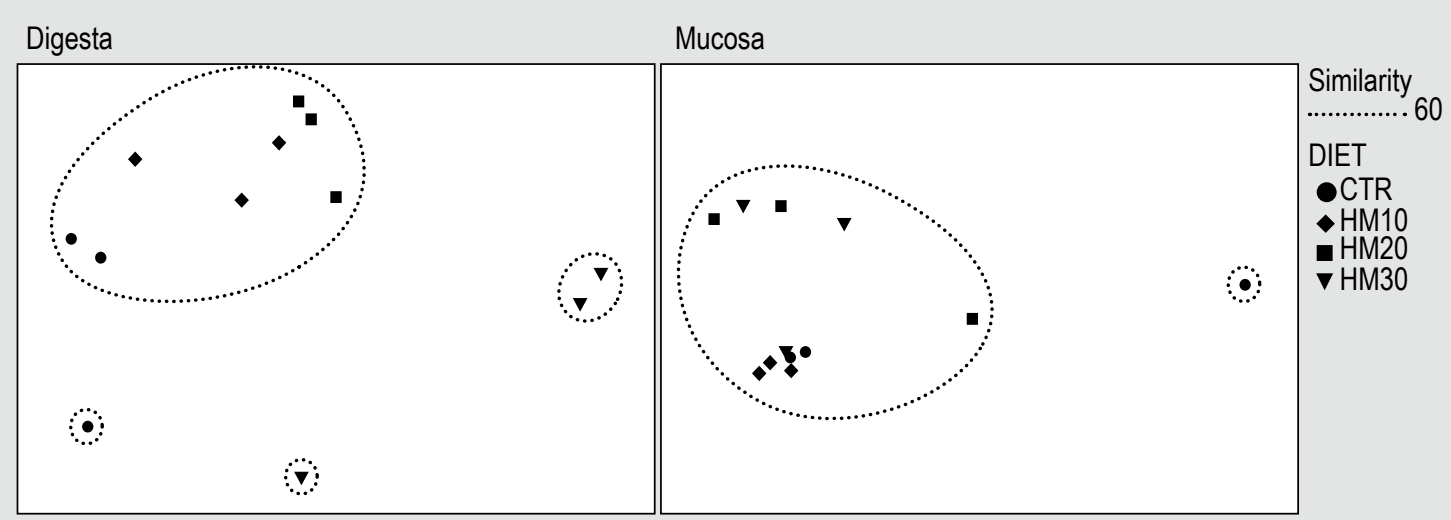

Figure 3. Non-metric multidimensional scaling plot of denaturing gradient gel electrophoresis bands presence and abundances of meagre fed the experimental diets depicted in Figure 2.

Additionally, in digesta, none of the HM30 replicates was closely related to any of the other diets.

The absence of a generalised clustering correlates with the lack of dietary effect in operational taxonomic units,
Margalef species richness index, Shannon's diversity index, and SIMPER similarity both in allochthonous and autochthonous microbial communities (Table 3). 
Table 3. Ecological parameters estimated from PCR-DGGE fingerprints of gut allochthonous (digesta) and autochthonous microbiota (mucosa) of meagre fed the control (CTR) and the Hermetia illucens meal (HM) diets. ${ }^{1}$

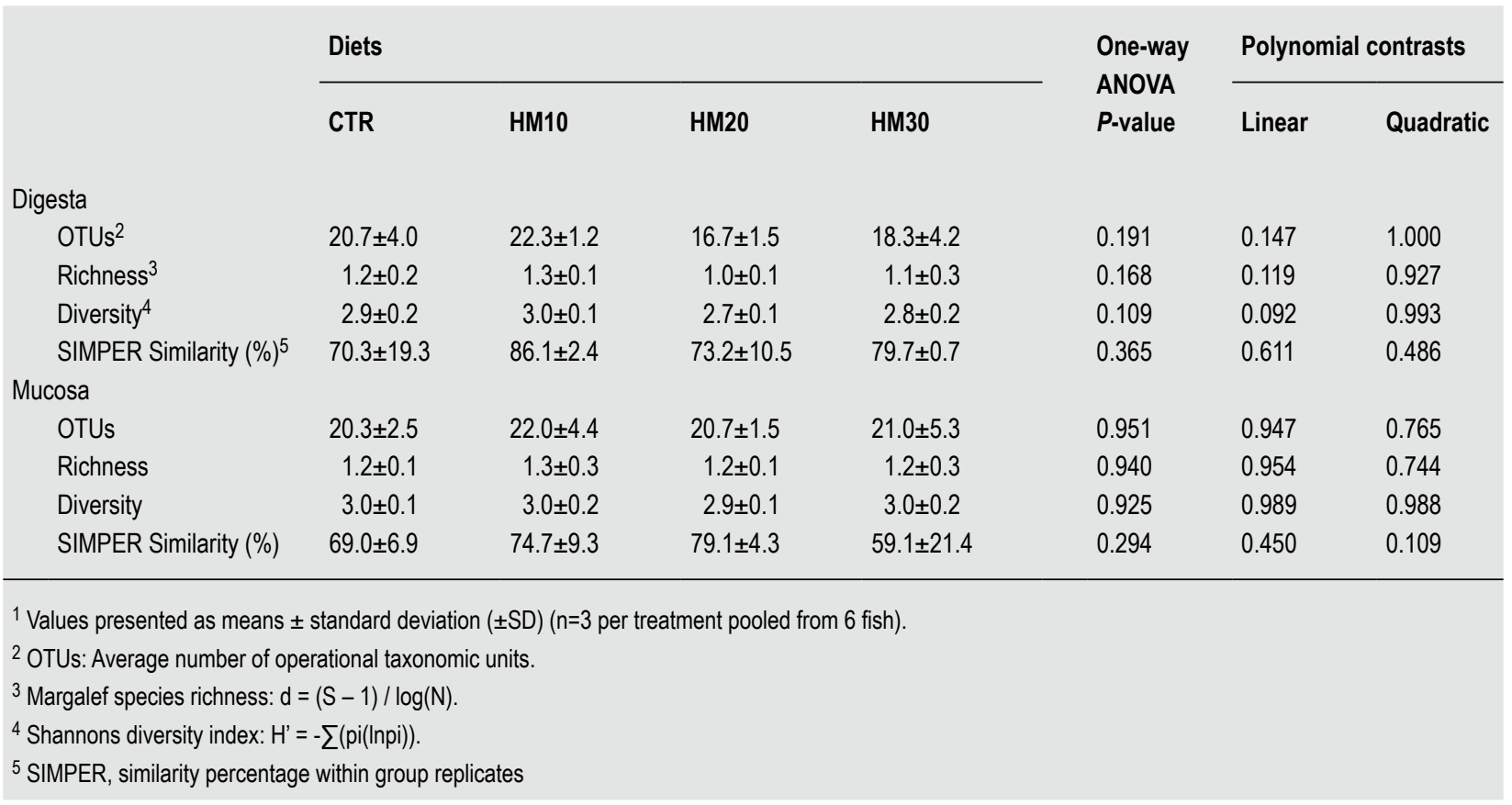

Sequence analysis of selected DGGE bands (Figure 2; Table 4) showed that the detected dominant autochthonous bacteria were either corresponding to uncultured bacteria not yet assigned to specific taxa or were closely related to Pseudomonas, Flavobacterium, Bacillus, Burkholderia and Methylobacterium genera.

\section{Humoral immune parameters}

Except for plasma anti-protease activity, which increased with dietary HM level, no other differences were observed in the plasmatic humoral immune parameters evaluated (Table 5).

Table 4. Bacterial species identified from the DNA sequencing of the autochthonous gut communities of meagre fed the experimental diets.

$\begin{array}{llcl}\begin{array}{l}\text { Band } \\ \text { number }\end{array} & \text { Closest known species } & \begin{array}{l}\text { Identity } \\ \text { (\%) }\end{array} & \begin{array}{l}\text { Accession } \\ \text { number }\end{array} \\ 1 & & 91.9 & \text { HM483780.1 } \\ 2 & \text { Uncultured bacterium clone TG_BD0.7_WB048 16S ribosomal RNA, partial sequence } & 92.6 & \text { AJ495677.1 } \\ 3 & \text { Uncultured low G+C Gram-positive bacterium partial 16S rRNA gene, isolate SB-31 } & 94.1 & \text { MT377837.1 } \\ 4 & \text { Pseudomonas sp. strain MT17 16S ribosomal RNA gene, partial sequence } & 99.3 & \text { MT641229.1 } \\ 5 & \text { Pseudomonas extremaustralis strain WS-1 16S ribosomal RNA gene, partial sequence } & 94.4 & \text { MT636597.1 } \\ 6 & \text { Flavobacterium haoranii strain NBU2616 16S ribosomal RNA gene, partial sequence } & 91.6 & \text { HE962831.1 } \\ 7 & \text { Uncultured bacterium partial 16S rRNA gene, clone NY10_CLONE_g07 } & 93.0 & \text { MK217090.1 } \\ 8 & \text { Bacillus subtilis strain sn18 16S ribosomal RNA gene, partial sequence } & 90.8 & \text { KY945632.1 } \\ 9 & \text { Burkholderia sp. strain HBUM200490 16S ribosomal RNA gene, partial sequence } & 96.2 & \text { KY857639.1 } \\ 10 & \text { Uncultured bacterium clone ac-25 16S ribosomal RNA gene, partial sequence } & 99.1 & \text { LC038939.1 } \\ 11 & \text { Uncultured Methylobacterium sp. gene for 16S rRNA, partial sequence, clone: SB-P-2-D06 } & 98.2 & \text { HM249499.1 }\end{array}$


Table 5. Plasma humoral immune parameters of meagre fed the control (CTR) and the Hermetia illucens meal (HM) diets. ${ }^{1,2}$

\begin{tabular}{|c|c|c|c|c|c|c|c|}
\hline & \multicolumn{4}{|l|}{ Diets } & \multirow{2}{*}{$\begin{array}{l}\text { One-way } \\
\text { ANOVA } \\
P \text {-value }\end{array}$} & \multicolumn{2}{|c|}{ Polynomial contrasts } \\
\hline & CTR & HM10 & HM2O & НM30 & & Linear & Quadratic \\
\hline Protease activity (\%) & $6.2 \pm 1.0$ & $6.2 \pm 1.0$ & $6.7 \pm 0.9$ & $6.6 \pm 1.1$ & 0.901 & 0.582 & 0.938 \\
\hline Anti-protease activity (\%) & $78.4 \pm 0.8^{\mathrm{a}}$ & $79.1 \pm 0.5^{\mathrm{ab}}$ & $79.3 \pm 1.0^{\mathrm{ab}}$ & $80.3 \pm 0.4^{b}$ & 0.055 & 0.011 & 0.779 \\
\hline Peroxidase (U/ml) & $40.4 \pm 5.7$ & $37.3 \pm 6.6$ & $44.8 \pm 20.6$ & $32.8 \pm 8.1$ & 0.667 & 0.629 & 0.540 \\
\hline Nitric Oxide $(\mu \mathrm{M})$ & $465 \pm 11.3$ & $416.1 \pm 59.6$ & $489.8 \pm 111.5$ & $432.6 \pm 59.3$ & 0.598 & 0.900 & 0.922 \\
\hline Total immunoglobulin (mg/ml) & $13.5 \pm 0.7$ & $14.3 \pm 0.6$ & $13.4 \pm 1.4$ & $14.9 \pm 1.5$ & 0.350 & 0.279 & 0.573 \\
\hline Lysozyme ( $\mu \mathrm{g} / \mathrm{ml})$ & $3.8 \pm 0.1$ & $5.4 \pm 1.1$ & $5.1 \pm 0.1$ & $4.1 \pm 1.3$ & 0.155 & 0.806 & 0.035 \\
\hline Bactericidal activity (\%) & $43.7 \pm 5.9$ & $40.3 \pm 4.1$ & $41.0 \pm 5.0$ & $38.7 \pm 2.7$ & 0.630 & 0.269 & 0.835 \\
\hline
\end{tabular}

\section{Discussion}

The gut provides a good indication of fish performance and health as it is involved in digestive and absorptive processes and immune defence (Zhang et al., 2020). It is one of the first organs to interact with dietary inputs, and evaluation of gut histomorphology and microbiota composition may provide an indication of fish health status in relation to diet composition.

In the present study, the dietary inclusion of a partially defatted HM up to $30 \%$ did not lead to significant alterations in the DI, namely regarding mucosal folds height, width and cellularity of the lamina propria and submucosa, nucleus position within the enterocytes, and variation of vacuolisation and enterocyte shape. Fish response to dietary inclusion of insect meal is species-specific and depends on the insect meal source and characteristics of the meal (Gasco et al., 2020c). However, dietary inclusion of HM usually does not lead to remarkable adverse effects on fish gut morphology. For instance, dietary inclusion of 20, 25 and $100 \%$ full-fat HM had no impact on gut histology of rainbow trout, Atlantic salmon, and zebrafish, respectively (Józefiak et al., 2019a; Lock et al., 2016; Zarantoniello et al., 2020). Further, dietary inclusion of partially defatted HM up to $40 \%$ also had no adverse effects on rainbow trout gut integrity (Elia et al., 2018; Renna et al., 2017). In Japanese seabass and Siberian sturgeon up to 19 and $37.5 \%$ of defatted HM, respectively, could be included in the diets without affecting anterior and distal intestine morphology (Caimi et al., 2020; Wang et al., 2019).

In the present study, an increasing number of eosinophilic granulocytes and intraepithelial leukocytes were observed with dietary HM inclusion level. Although these parameters are potentially indicative of gut inflammation and are often reported in fish fed plant protein-based diets (Guerreiro et al., 2015; Krogdahl et al., 2003; Santigosa et al., 2008), no other signs of gut inflammation were observed in the present study.

For the minor effects on gut inflammation observed in juvenile meagre, may have contributed the richness of HM in saturated fatty acids, especially lauric acid, which is known to have positive effects on gut health (Gasco et al., 2018). To our knowledge, increased submucosa cellularity in the proximal intestine, suggesting gut inflammation, has only been reported in a study with Atlantic salmon fed a diet with around 15\% of a partially defatted HM (Li et al., 2020). However, the authors also highlighted that this response was not supported by the expression of the pro-inflammatory genes analysed.

The immune cells infiltrate observed herein in fish fed the HM diets, may be related to the presence of compounds recognised as foreign, namely chitin, and the consequent migration of immune cells to the site of contact. Although meagre natural food is mostly composed of fish and crustaceans, it is unable to digest chitin as no chitinolytic activity was detected in meagre intestine (Guerreiro et al., 2021). Similarly, in mice, chitin acts as a recognition element for tissue infiltration by innate immune cells implicated in allergic immunity, namely eosinophils and basophils (Reese et al., 2007).

Overall, although gut histomorphological alterations were minor, a local immune response was induced with the increase of dietary HM levels, and such effect was in line with the decrease of diet digestibility and growth performance of the fish, as reported elsewhere (Guerreiro et al., 2020, 2021).

The bacteria genera identified in meagre autochthonous population were similar to that found in other carnivorous 
fish gut, including European seabass (Nikouli et al., 2018; Serra et al., 2021), gilthead seabream (Nikouli et al., 2018), Atlantic salmon (Gajardo et al., 2016; Villasante et al., 2019), or rainbow trout (Rimoldi et al., 2018). Bacteria belonging to Pseudomonas and Burkholderia genera, which include pathogenic species but also potential probiotic strains, are abundant in aquatic environments and were previously found at high levels in European seabass, gilthead seabream, Atlantic salmon, and rainbow trout gut (Gajardo et al., 2016; Nikouli et al., 2018; Rimoldi et al., 2018; Serra et al., 2021). Bacillus spp., mostly associated with beneficial characteristics, were also reported to be highly prevalent in the gut of European seabass, gilthead seabream, white seabream (Diplodus sargus) (Santos et al., 2021; Serra et al., 2019), Atlantic salmon (Gajardo et al., 2016; Villasante et al., 2019), and rainbow trout (Rimoldi et al., 2018). Flavobacterium and Methylobacterium, although not considered highly abundant genera within fish guts, are common in the aquatic environment, and have been associated with the skin microbiota of the brook charr (Salvelinus fontinalis) (Boutin et al., 2014).

Regardless of the insect's life cycle stage (larvae or prepupa), defatting process and dietary inclusion level, the use of HM was shown to increase gut microbiota diversity or richness in rainbow trout, Siberian sturgeon and Atlantic salmon (Bruni et al., 2018; Huyben et al., 2019; Józefiak et al., 2019a,b; Li et al., 2021; Rimoldi et al., 2019; Terova et al., 2019). Moreover, HM induced a shift of fish gut microbiota towards an increase of beneficial bacteria from the Firmicutes and Actinobacteria phyla, at the expense of Proteobacteria, a gram-negative phylum containing pathogens. Within Firmicutes, HM enhanced gut colonisation by lactic acid-producing bacteria (LAB), especially Lactobacillaceae, often used as probiotics (Bruni et al., 2018; Huyben et al., 2019; Terova et al., 2019), and butyrate-producing bacteria belonging to the Clostridium genus (Józefiak et al., 2019b). Regarding Actinobacteria, HM increased the number of chitin-degrading bacteria belonging to genera Actinomyces and Corynebacterium (Huyben et al., 2019; Terova et al., 2019). In contrast, present data pointed to a lack of dietary HM effect in allochthonous and autochthonous gut microbial diversity and richness. This was somewhat unexpected, regarding results of previous studies in other species, and requires to be further elucidated.

The positive effects of $\mathrm{HM}$ on fish gut microbiota have been mainly attributed to chitin, which has potential prebiotic properties and is a major substrate for LAB fermentation (Askarian et al., 2012; Ringø et al., 2012). Additionally, chitin also has antimicrobial and bacteriostatic properties against several Proteobacteria (Nawaz et al., 2018; Udayangani et al., 2017). In the present study, dietary chitin content in the HM diets ranged from 0.6 to 1.6\% DM (Guerreiro et al., 2020), and these levels might not be enough to affect meagre gut microbiota composition. Nonetheless, in studies with other species, diets with a similar chitin content as those used in the present study exerted a positive effect in fish gut microbiota composition (Rimoldi et al., 2019; Terova et al., 2019).

The feeding substrates used during insects rearing can also interfere with the bacterial community of fish gastrointestinal tract. Thus, Osimani et al. (2019) showed that the microbiota of $H$. illucens reared on a vegetable substrate presented a higher richness compared to a coffee by-product. Additionally, an influence of the microbiota of H. illucens and/or insect-derived bioactive compounds, was also observed on the gut microbiota of zebrafish fed with the HM meals (Osimani et al., 2019). Although in the present study details on $H$. illucens rearing were not provided by the insect meal industry, the influence of the feeding substrates in the absence of fish microbiota positive results cannot be discharged.

Nutrition is an important vehicle for immunomodulation in fish (Kiron, 2012). Overall, insect meals have been shown to enhance fish immune function and improve resistance against pathogens (Abdel-Latif et al., 2021; Chaklader et al., 2019; Li et al., 2019; Sankian et al., 2018; Su et al., 2017). Concerning HM, the supplementation of a $45 \%$ poultry by-product diet with $10 \% \mathrm{HM}$ enhanced barramundi disease resistance against $V$. harveyi through modulating fish immune response (Chaklader et al., 2019). In Atlantic salmon posterior and distal intestine, a diet with $60 \% \mathrm{HM}$ led to a up-regulation of $\operatorname{cd} 3 \gamma \delta$ and foxp3, components of the $\mathrm{T}$ cell receptor complex, compared to fish fed the reference diet (Li et al., 2019). An increase of the nonspecific immune indices, phagocytic activity, phagocytic index, serum lysozyme and respiratory burst activities as well as an up-regulation of the mRNA expression levels of hepatic interleukin- $1 \beta$ and interleukin- 10 genes was observed in European seabass fed diets up to 15\% HM inclusion (Abdel-Latif et al., 2021).

Present data showed that dietary inclusion of HM increased the plasma anti-protease activity, while no other innate immune-related parameter measured was affected. Anti-proteases, namely $\alpha-1$ protease inhibitors and $\alpha-2$ macroglobulins, act against microbial proteases, thus protecting the host from infections (Ellis, 2001). This anti-protease activity enhancement might be related to the presence of polysaccharides such as chitin, silkrose or dipterose in insects (Cuesta et al., 2003; Esteban et al., 2000, 2001; Gopalakannan and Arul, 2006; Harikrishnan et al., 2012; Ohta et al., 2014, 2016; Shanthi et al., 2014).

To obtain a positive effect with an immunostimulant it is desirable an increase in both proteases and anti-proteases (Cerezuela et al., 2016), which was not observed in the present study. Additionally, an absence of HM effect on all 
other humoral immune parameters assessed was recorded. However, recent findings by Henry et al. (2018a,b) suggested that anti-protease increased activity promotes a better potential of insect-fed fish to fight parasitic infection. Thus, further studies are needed to support the positive HM effect on anti-protease activity, namely the performance of challenge studies.

In conclusion, present results indicate that dietary HM inclusion had minor effects on gut microbiota diversity and humoral immune status. Nevertheless, dietary HM induced minor gut histomorphological alterations, which might compromise meagre health condition, diet digestibility and growth performance, which is in line with results already published (Guerreiro et al., 2020, 2021).

\section{Acknowledgements}

This research was supported by national funds through FCT - Foundation for Science and Technology within the scope of UIDB/04423/2020 and UIDP/04423/2020, and by PP IJUP2017-SOJA DE PORTUGAL-33. The researchers I.G., C.C., F.R., M.M. and R.S. were supported by grants from FCT, Portugal (SFRH/BPD/114959/2016, SFRH/BPD/114942/2016, SFRH/BD/138375/2018, SFRH/BD/114995/2016, and SFRH/BD/131069/2017, respectively). F.C. had a research contract under the FCT project POCI-01-0145-FEDER-029540 (PTDC/BIAOUT/29540/2017). P.E., A.C. and C.R.S. had scientific employment contracts supported by national funds through FCT.

This project has partially received funding by the European Union's Horizon 2020 research and innovation programme under grant agreement no. 861976. This document reflects only the author's view and the Commission is not responsible for any use that may be made of the information it contains.

\section{Conflict of interest}

The authors declare no conflict of interest.

\section{References}

Abdel-Latif, H.M.R., Abdel-Tawwab, M., Khalil, R.H., Metwally, A.A., Shakweer, M.S., Ghetas, H.A. and Khallaf, M.A., 2021. Black soldier fly (Hermetia illucens) larvae meal in diets of European seabass: effects on antioxidative capacity, non-specific immunity, transcriptomic responses, and resistance to the challenge with Vibrio alginolyticus. Fish \& Shellfish Immunology 111: 111-118. https://doi.org/10.1016/j.fsi.2021.01.013
Abdel-Tawwab, M., Khalil, R.H., Metwally, A.A., Shakweer, M.S., Khallaf, M.A. and Abdel-Latif, H.M., 2020. Effects of black soldier fly (Hermetia illucens L.) larvae meal on growth performance, organs-somatic indices, body composition, and hemato-biochemical variables of European sea bass, Dicentrarchus labrax. Aquaculture 522: 735136. https://doi.org/10.1016/j.aquaculture.2020.735136

Antonopoulou, E., Nikouli, E., Piccolo, G., Gasco, L., Gai, F., Chatzifotis, S., Mente, E. and Kormas, K.A., 2019. Reshaping gut bacterial communities after dietary Tenebrio molitor larvae meal supplementation in three fish species. Aquaculture 503: 628-635. https://doi.org/10.1016/j.aquaculture.2018.12.013

Askarian, F., Zhou, Z., Olsen, R.E., Sperstad, S. and Ringo, E., 2012. Culturable autochthonous gut bacteria in Atlantic salmon (Salmo salar L.) fed diets with or without chitin. Characterization by $16 \mathrm{~S}$ rRNA gene sequencing, ability to produce enzymes and in vitro growth inhibition of four fish pathogens. Aquaculture 326: 1-8. https://doi.org/10.1016/j.aquaculture.2011.10.016

Belghit, I., Liland, N.S., Gjesdal, P., Biancarosa, I., Menchetti, E., Li, Y., Waagbø, R., Krogdahl, Å. and Lock, E.-J., 2019. Black soldier fly larvae meal can replace fish meal in diets of sea-water phase Atlantic salmon (Salmo salar). Aquaculture 503: 609-619. https:// doi.org/10.1016/j.aquaculture.2018.12.032

Belghit, I., Liland, N.S., Waagbø, R., Biancarosa, I., Pelusio, N., Li, Y., Krogdahl, Å. and Lock, E.-J., 2018. Potential of insect-based diets for Atlantic salmon (Salmo salar). Aquaculture 491: 72-81. https:// doi.org/10.1016/j.aquaculture.2018.03.016

Boutin, S., Sauvage, C., Bernatchez, L., Audet, C. and Derome, N., 2014. Inter individual variations of the fish skin microbiota: host genetics basis of mutualism? PLoS ONE 9(7): e102649. https://doi. org/10.1371/journal.pone.0102649

Bruni, L., Pastorelli, R., Viti, C., Gasco, L. and Parisi, G., 2018. Characterization of the intestinal microbial communities of rainbow trout (Oncorhynchus mykiss) fed with Hermetia illucens (black soldier fly) partially defatted larva meal as partial dietary protein source. Aquaculture 487: 56-63. https://doi.org/10.1016/j. aquaculture.2018.01.006

Caimi, C., Gasco, L., Biasato, I., Malfatto, V., Varello, K., Prearo, M., Pastorino, P., Bona, M.C., Francese, D.R., Schiavone, A., Elia, A.C., Dörr, A.J.M. and Gai, F., 2020. Could dietary black soldier fly meal inclusion affect the liver and intestinal histological traits and the oxidative stress biomarkers of Siberian Sturgeon (Acipenser baerii) juveniles? Animals 10: 155. https://doi.org/10.3390/ani10010155

Cardinaletti, G., Randazzo, B., Messina, M., Zarantoniello, M., Giorgini, E., Zimbelli, A., Bruni, B., Parisi, G., Olivotto, I. and Tulli, F., 2019. Effects of graded dietary inclusion level of full-fat hermetia illucens prepupae meal in practical diets for rainbow trout (Oncorhynchus mykiss). Animals 9(5): 251. https://doi.org/10.3390/ani9050251

Cerezuela, R., Guardiola, F.A., Cuesta, A. and Esteban, A., 2016. Enrichment of gilthead seabream (Sparus aurata L.) diet with palm fruit extracts and probiotics: effects on skin mucosal immunity. Fish \& Shellfish Immunology 49: 100e109. https://doi.org/10.1016/j. fsi.2015.12.028 
Chaklader, M.R., Siddik, M.A.B., Fotedar, R. and Howieson, J., 2019. Insect larvae, Hermetia illucens in poultry by-product meal for barramundi, Lates calcarifer modulates histomorphology, immunity and resistance to Vibrio harveyi. Scientific Reports 9: 16703. https:// doi.org/10.1038/s41598-019-53018-3

Clarke, K.R. and Warwick, R.M., 2001. Change in marine communities: an approach to statistical analysis and interpretation, $2^{\text {nd }}$ edition. PRIMER-E, Plymouth, UK, $176 \mathrm{pp}$.

Couto, A., Barroso, C., Guerreiro, I., Pousão-Ferreira, P., Matos, E., Peres, H., Oliva-Teles, A. and Enes, P., 2016. Carob seed germ meal in diets for meagre (Argyrosomus regius) juveniles: growth, digestive enzymes, intermediary metabolism, liver and gut histology. Aquaculture 451: 396-404. https://doi.org/10.1016/j. aquaculture.2015.10.007

Cuesta, A., Esteban, M.Á. and Meseguer, J., 2003. In vitro effect of chitin particles on the innate cellular immune system of gilthead seabream (Sparus aurata L.). Fish \& Shellfish Immunology 15: 1-11. https://doi.org/10.1016/S1050-4648(02)00134-1

Egerton, S., Culloty, S., Whooley, J., Stanton, C. and Ross, R.P., 2018. The gut microbiota of marine fish. Frontiers in Microbiology 9: 873. https://doi.org/10.3389/fmicb.2018.00873

Elia, A.C., Capucchio, M.T., Caldaroni, B., Magara, G., Dörr, A.J.M., Biasato, I., Biasibetti, E., Righetti, M., Pastorino, P., Prearo, M., Gai, F., Schiavone, A. and Gasco, L., 2018. Influence of Hermetia illucens meal dietary inclusion on the histological traits, gut mucin composition and the oxidative stress biomarkers in rainbow trout (Oncorhynchus mykiss). Aquaculture 496: 50-57. https://doi. org/10.1016/j.aquaculture.2018.07.009

Ellis, A.E., 2001. Innate host defense mechanisms of fish against viruses and bacteria. Development \& Comparative Immunology 25: 827839. https://doi.org/10.1016/S0145-305X(01)00038-6

Esteban, M.A., Cuesta, A., Ortuño, J. and Meseguer, J., 2001. Immunomodulatory effects of dietary intake of chitin on gilthead seabream (Sparus aurata L.) innate immune system. Fish \& Shellfish Immunology 11: 303-315. https://doi.org/10.1006/fsim.2000.0315

Esteban, M.A., Mulero, V., Cuesta, A., Ortuño, J. and Meseguer, J., 2000. Effects of injecting chitin particles on the innate immune response of gilthead seabream (Sparus aurata L.). Fish \& Shellfish Immunology 10: 543-554. https://doi.org/10.1006/fsim.2000.0271

Gajardo, K., Rodiles, A., Kortner, T.M., Krogdahl, Å., Bakke, A.M., Merrifield, D.L. and Sørum, H., 2016. A high-resolution map of the gut microbiota in Atlantic salmon (Salmo salar): a basis for comparative gut microbial research. Scientific Reports 6: 30893. https://doi.org/10.1038/srep30893

Gasco, L., Acuti, G., Bani, P., Dalle Zotte, A., Danieli, P.P., De Angelis, A., Fortina, R., Marino, R., Parisi, G., Piccolo, G., Pinotti, L., Prandini, A., Schiavone, A., Terova, G., Tulli, F. and Roncarati, A., 2020a. Insect and fish by-products as sustainable alternatives to conventional animal proteins in animal nutrition. Italian Journal of Animal Science 19: 360-372. https://doi.org/10.1080/182805 1X.2020.1743209

Gasco, L., Biancarosa, I. and Liland, N.S., 2020b. From waste to feed: a review of recent knowledge on insects as producers of protein and fat for animal feeds. Current Opinion in Green and Sustainable Chemistry 23: 67-79. https://doi.org/10.1016/j.cogsc.2020.03.003
Gasco, L., Finke, M. and Van Huis, A., 2018. Can diets containing insects promote animal health? Journal of Insects as Food and Feed 4: 1-4. https://doi.org/10.3920/JIFF2018.x001

Gasco, L., Józefiak, A. and Henry, M., 2020c. Beyond the protein concept: health aspects of using edible insects on animals. Journal of Insects as Food and Feed 7(5): 715-741. https://doi.org/10.3920/ JIFF2020.0077

Gopalakannan, A. and Arul, V., 2006. Immunomodulatory effects of dietary intake of chitin, chitosan and levamisole on the immune system of Cyprinus carpio and control of Aeromonas hydrophila infection in ponds. Aquaculture 255: 179-187. https://doi. org/10.1016/j.aquaculture.2006.01.012

Graham, S., Jeffries, A.H. and Secombes, C.J., 1988. A novel assay to detect macrophage bactericidal activity in fish: factors influencing the killing of Aeromonas salmonicida. Journal of Fish Diseases 11: 389-396. https://doi.org/10.1111/j.1365-2761.1988.tb00734.x Guardiola, F.A., Barroso, C., Enes, P., Couto, A., Diaz-Rosales, P., Afonso, A., Kanashiro, E., Peres, H., Matos, E., Oliva-Teles, A., Pousão-Ferreira, P. and Costas, B., 2018. Humoral and mucosal immune responses in meagre (Argyrosomus regius) juveniles fed diets with varying inclusion levels of carob seed germ meal. Fish \& Shellfish Immunology 79: 209-217. https://doi.org/10.1016/j. fsi.2018.05.027

Guerreiro, I., Castro, C., Antunes, B., Coutinho, F., Rangel, F., Couto, A., Serra, C.R., Peres, H., Pousão-Ferreira, P., Matos, E., Gasco, L., Gai, F., Corraze, G., Oliva-Teles, A. and Enes, P., 2020. Catching black soldier fly for meagre: Growth, whole-body fatty acid profile and metabolic responses. Aquaculture 516: 734613. https://doi. org/10.1016/j.aquaculture.2019.734613

Guerreiro, I., Couto, A., Pérez-Jiménez, A., Oliva-Teles, A. and Enes, P., 2015. Gut morphology and hepatic oxidative status of European sea bass (Dicentrarchus labrax) juveniles fed plant feedstuffs or fishmealbased diets supplemented with short-chain fructo oligosaccharides and xylo-oligosaccharides. British Journal of Nutrition 114: 19751984. https://doi.org/10.1017/S0007114515003773

Guerreiro, I., Serra, C.R., Coutinho, F., Couto, A., Castro, C., Rangel, F., Peres, H., Pousão-Ferreira, P., Matos, E., Gasco, L., Gai, F., OlivaTeles, A. and Enes, P., 2021. Digestive enzymes activity and nutrients digestibility in meagre (Argyrosomus regius) fed black soldier fly (Hermetia illucens). Aquaculture Nutrition 27: 142-152. https:// doi.org/10.1111/anu.13172

Harikrishnan, R., Kim, J.-S., Balasundaram, C. and Heo, M.S., 2012. Immunomodulatory effects of chitin and chitosan enriched diets in Epinephelus bruneus against Vibrio alginolyticus infection. Aquaculture 326-329: 46-52. https://doi.org/10.1016/j. aquaculture.2011.11.034

Hawkey, K.J., Lopez-Viso, C., Brameld, J.M., Parr, T. and Salter, A.M., 2021. Insects: a potential source of protein and other nutrients for feed and food. Annual Review of Animal Biosciences 9: 333-54. https://doi.org/10.1146/annurev-animal-021419-083930

Henry, M., Gasco, L., Chatzifotis, S. and Piccolo, G., 2018b. Does dietary insect meal affect the fish immune system? The case of mealworm, Tenebrio molitor on European sea bass, Dicentrarchus labrax. Developmental \& Comparative Immunology 81: 204-209. https://doi.org/10.1016/j.dci.2017.12.002 
Henry, M.A., Gai, F., Enes, P., Peréz-Jiménez, A. and Gasco, L., 2018a. Effect of partial dietary replacement of fishmeal by yellow mealworm (Tenebrio molitor) larvae meal on the innate immune response and intestinal antioxidant enzymes of rainbow trout (Oncorhynchus mykiss). Fish \& Shellfish Immunology 83: 308-313. https://doi. org/10.1016/j.fsi.2018.09.040

Huyben, D., Vidakovic, A., Werner Hallgren, S. and Langeland, M., 2019. High-throughput sequencing of gut microbiota in rainbow trout (Oncorhynchus mykiss) fed larval and pre-pupae stages of black soldier fly (Hermetia illucens). Aquaculture 500: 485-491. https://doi.org/10.1016/j.aquaculture.2018.10.034

Józefiak, A., Nogales-Merida, S., Mikołajczak, Z. and Mazurkiewicz, J., 2019a. The utilization of full-fat insect meal in rainbow trout (Oncorhynchus mykiss) nutrition: the effects on growth performance, intestinal microbiota and gastro-intestinal tract histomorphology. Annals of Animal Science 19: 747-765. https://doi.org/10.2478/ aoas-2019-0020

Józefiak, A., Nogales-Merida, S., Rawski, M., Kieronczyk, B. and Mazurkiewicz, J., 2019b. Effects of insect diets on the gastrointestinal tract health and growth performance of Siberian sturgeon (Acipenser baerii Brandt, 1869). BMC Veterinary Research 15: 348. https://doi. org/10.1186/s12917-019-2070-y

Karapanagiotidis, I., Daskalopoulou, E., Vogiatzis, I., Rumbos, C., Mente, E. and Athanassiou, C., 2014. Substitution of fishmeal by fly Hermetia illucens prepupae meal in the diet of gilthead seabream (Sparus aurata). HydroMedit 13-15: 110-114.

Kiron, V., 2012. Fish immune system and its nutritional modulation for preventive health care. Animal Feed Science and Technology 173: 111-133. https://doi.org/10.1016/j.anifeedsci.2011.12.015

Kroeckel, S., Harjes, A., Roth, I., Katz, H., Wuertz, S., Susenbeth, A. and Schulz, C., 2012. When a turbot catches a fly: evaluation of a pre-pupae meal of the black soldier fly (Hermetia illucens) as fish meal substitute - growth performance and chitin degradation in juvenile turbot (Psetta maxima). Aquaculture 364: 345-352.

Krogdahl, Å., Bakke-McKellep, A.M. and Baeverfjord, G., 2003. Effects of graded levels of standard soybean meal on intestinal structure, mucosal enzyme activities, and pancreatic response in Atlantic salmon (Salmo salar L.). Aquaculture Nutrition 9: 361-371. https:// doi.org/10.1046/j.1365-2095.2003.00264.x

Li, Y., Bruni, L., Jaramillo-Torres, A., Gajardo, K., Kortner, T.M. and Krogdahl, Å., 2021. Differential response of digesta- and mucosaassociated intestinal microbiota to dietary black soldier fly (hermetia illucens) larvae meal in seawater phase Atlantic salmon (Salmo salar). Animal Microbiome 3: 8. https://doi.org/10.1101/2020.05.08.083899

Li, Y., Kortner, T.M., Chikwati, E.M., Belghit, I., Lock, E.-J. and Krogdahl, Å., 2020. Total replacement of fish meal with black soldier fly (Hermetia illucens) larvae meal does not compromise the gut health of Atlantic salmon (Salmo salar). Aquaculture 520: 734967. https://doi.org/10.1016/j.aquaculture.2020.734967

Li, Y., Kortner, T.M., Chikwati, E.M., Munang'andu, H.M., Lock, E.-J. and Krogdahl, Å., 2019. Gut health and vaccination response in presmolt Atlantic salmon (Salmo salar) fed black soldier fly (Hermetia illucens) larvae meal. Fish \& Shellfish Immunology 86: 1106-1113. https://doi.org/10.1016/j.fsi.2018.12.057
Llewellyn, M.S., Boutin, S., Hoseinifar, S.H. and Derome, N., 2014. Teleost microbiomes: the state of the art in their characterization, manipulation and importance in aquaculture and fisheries. Frontiers in Microbiology 5: 207. https://doi.org/10.3389/fmicb.2014.00207

Lock, E.R., Arsiwalla, T. and Waagbø, R., 2016. Insect larvae meal as an alternative source of nutrients in the diet of Atlantic salmon (Salmo salar) postsmolt. Aquaculture Nutrition 22: 1202-1213. https://doi.org/10.1111/anu.12343

Magalhães, R., Sanchez-Lopez, A., Leal, R.S., Martinez-Llorens, S., Oliva-Teles, A. and Peres, H., 2017. Black soldier fly (Hermetia illucens) pre-pupae meal as a fish meal replacement in diets for European seabass (Dicentrarchus labrax). Aquaculture 476: 79-85. https://doi.org/10.1016/j.aquaculture.2017.04.021

Mastoraki, M., Ferrándiz, P.M., Vardali, S.C., Kontodimas, D.C., Kotzamanis, Y.P., Gasco, L., Chatzifotis, S. and Antonopoulou, E., 2020. A comparative study on the effect of fish meal substitution with three different insect meals on growth, body composition and metabolism of European sea bass (Dicentrarchus labrax L.). Aquaculture 528: 735511. https://doi.org/10.1016/j. aquaculture.2020.735511

Muyzer, G., De Waal, E.C. and Uitterlinden, A.G., 1993. Profiling of complex microbial populations by denaturing gradient gel electrophoresis analysis of polymerase chain reaction-amplified genes coding for 16S rRNA. Applied and Environmental Microbiology 59: 695-700.

Nawaz, A., Bakhsh Javaid, A., Irshad, S., Hoseinifar, S.H. and Xiong, H., 2018. The functionality of prebiotics as immunostimulant: evidences from trials on terrestrial and aquatic animals. Fish \& Shellfish Immunology 76: 272-278. https://doi.org/10.1016/j.fsi.2018.03.004

Nikouli, E., Meziti, A., Antonopoulou, E., Mente, E. and Kormas, K.A., 2018. Gut bacterial communities in geographically distant populations of farmed sea bream (Sparus aurata) and sea bass (Dicentrarchus labrax). Microorganisms 6: 92. https://doi. org/10.3390/microorganisms6030092

Nogales-Mérida, S., Gobbi, P., Józefiak, D., Mazurkiewicz, J., Dudek, K., Rawski, M., Kieronczyk, B. and Józefiak, A., 2019. Insect meals in fish nutrition. Reviews in Aquaculture 11: 1080-1103. https:// doi.org/10.1111/raq.12281

Ohta, T., Ido, A., Kusano, K., Miura, C. and Miura, T.A., 2014. Novel polysaccharide in insects activates the innate immune system in mouse. PLoS ONE 9: e114823. https://doi.org/10.1371/journal. pone. 0114823

Ohta, T., Kusano, K., Ido, A., Miura, C. and Miura, T., 2016. Silkrose: a novel acidic polysaccharide from the silkmoth that can stimulate the innate immune response. Carbohydrate Polymers 136: 995-1001. https://doi.org/10.1016/j.carbpol.2015.09.070

Osimani, A., Milanović, V., Roncolini, A., Riolo, P., Ruschioni, S., Isidoro, N., Loreto, N., Franciosi, E., Tuohy, K., Olivotto, I., Zarantoniello, M., Cardinali, F., Garofalo, C., Aquilanti, L. and Clementi, F., 2019. Hermetia illucens in diets for zebrafish (Danio rerio): a study of bacterial diversity by using PCR-DGGE and metagenomic sequencing. PLoS ONE 14: e0225956. https://doi. org/10.1371/journal.pone.0225956 
Ravi, H.K., Degrou, A., Costil, J., Trespeuch, C., Chemat, F. and Vian, M.A., 2020. Larvae mediated valorization of industrial, agriculture and food wastes: biorefinery concept through bioconversion, processes, procedures, and products. Processes 8: 857. https:// doi.org/10.3390/pr8070857

Reese, T.A., Liang, H.E., Tager, A.M., Luster, A.D., Van Rooijen, N., Voehringer, D. and Locksley, R.M., 2007. Chitin induces accumulation in tissue of innate immune cells associated with allergy. Nature 447: 92-96. https://doi.org/10.1038/nature05746

Renna, M., Schiavone, A., Gai, F., Dabbou, S., Lussiana, C., Malfatto, V., Prearo, M., Capucchio, M.T., Biasato, I., Biasibetti, E., De Marco, M., Brugiapaglia, A., Zoccarato, I. and Gasco, L., 2017. Evaluation of the suitability of a partially defatted black soldier fly (Hermetia illucens L.) larvae meal as ingredient for rainbow trout (Oncorhynchus mykiss Walbaum) diets. Journal of Animal Science and Biotechnology 8: 57. https://doi.org/10.1186/s40104-017-0191-3

Rimoldi, S., Antonini, M., Gasco, L., Moroni, F. and Terova, G., 2021. Intestinal microbial communities of rainbow trout (Oncorhynchus mykiss) may be improved by feeding a Hermetia illucens meal/ low-fishmeal diet. Fish Physiology and Biochemistry 47: 365-380. https://doi.org/10.1007/s10695-020-00918-1S

Rimoldi, S., Gini, E., Iannini, F., Gasco, L. and Terova, G., 2019. The effects of dietary insect meal from Hermetia illucens prepupae on autochthonous gut microbiota of rainbow trout (Oncorhynchus mykiss). Animals 9: 143. https://doi.org/10.3390/ani9040143

Rimoldi, S., Terova, G., Ascione, C., Giannico, R. and Brambilla, F., 2018. Next generation sequencing for gut microbiome characterization in rainbow trout (Oncorhynchus mykiss) fed animal by-product meals. PLoS ONE 13(3): e0193652. https://doi.org/10.1371/journal. pone.0193652

Ringø, E., Zhou, Z., Olsen, R.E. and Song, S.K., 2012. Use of chitin and krill in aquaculture - the effect on gut microbiota and the immune system: a review. Aquaculture Nutrition 18: 117-131. https://doi. org/10.1111/j.1365-2095.2011.00919.x

Ross, N.W., Firth, K.J., Wang, A., Burka, J.F. and Johnson, S.C., 2000. Changes in hydrolytic enzyme activities of naive Atlantic salmon Salmo salar skin mucus due to infection with the salmon louse Lepeophtheirus salmonis and cortisol implantation. Diseases of Aquatic Organisms 41: 43-51. https://doi.org/10.3354/dao041043 Sankian, Z., Khsravi, S., Kim, Y.O. and Lee, S.M., 2018. Effects of dietary inclusion of yellow mealworm (Tenebrio molitor) meal on growth performance, feed utilization, body composition, plasma biochemical indices, selected immune parameters and antioxidant enzyme activities of mandarin fish (Siniperca scherzeri) juvenile. Aquaculture 496: 79-87. https://doi.org/10.1016/j. aquaculture.2018.07.012

Santigosa, E., Sánchez, J., Médale, F., Kaushik, S., Pérez-Sánchez, J. and Gallardo, M.A., 2008. Modifications of digestive enzymes in trout (Oncorhynchus mykiss) and sea bream (Sparus aurata) in response to dietary fish meal replacement by plant protein sources. Aquaculture 282: 68-74. https://doi.org/10.1016/j.aquaculture.2008.06.007

Santos, R.S., Oliva-Teles, A., Pousão-Ferreira, P., Jerusik, R., Saavedra, M.J., Enes, P. and Serra, C.R., 2021. Isolation and characterization of fish-gut bacillus spp. as source of natural antimicrobial compounds to fight aquaculture bacterial diseases. Marine Biotechnology 23: 276-293. https://doi.org/10.1007/s10126-021-10022-x
Serra, C.R., Almeida, E.M., Guerreiro, I., Santos, R., Merrifield, D.L., Tavares, F., Oliva-Teles, A. and Enes, P., 2019. Selection of carbohydrate-active probiotics from the gut of carnivorous fish fed plant-based diets. Scientific Reports 9: 6384. https://doi.org/10.1038/ s41598-019-42716-7

Serra, C.R., Oliva-Teles, A., Enes, P. and Tavares, F., 2021. Gut microbiota dynamics in carnivorous European seabass (Dicentrarchus labrax) fed plant-based diets. Scientific Reports 11: 447. https://doi.org/10.1038/s41598-020-80138-y

Shanthi Mari, L.S., Jagruthi, C., Anbazahan, S.M, Yogeshwari, G., Thirumurugan, R., Arockiaraj, J., Mariappan, P., Balasundaram, C. and Harikrishnan, R., 2014. Protective effect of chitin and chitosan enriched diets on immunity and disease resistance in Cirrhina mrigala against Aphanomyces invadans. Fish \& Shellfish Immunology 39: 378-385. https://doi.org/10.1016/j.fsi.2014.05.027

Stenberg, O.K., Holen, E., Piemontese, L., Liland, N.S., Lock, E.-J., Espe, M. and Belghit, I., 2019. Effect of dietary replacement of fish meal with insect meal on in vitro bacterial and viral induced gene response in Atlantic salmon (Salmo salar) head kidney leukocytes. Fish \& Shellfish Immunology 91: 223-232. https://doi.org/10.1016/j. fsi.2019.05.042

Su, J., Gong, Y., Cao, S., Lu, F., Han, D., Liu, H., Jin, J., Yang, Y., Zhu, X. and Xie, S., 2017. Effects of dietary Tenebrio molitor meal on the growth performance, immune response and disease resistance of yellow catfish (Pelteobagrus fulvidraco). Fish and Shellfish Immunology 69: 59-66. https://doi.org/10.1016/j.fsi.2017.08.008

Terova, G., Rimoldi, S., Ascione, C., Gini, E., Ceccotti, C. and Gasco, L., 2019. Rainbow trout (Oncorhynchus mykiss) gut microbiota is modulated by insect meal from Hermetia illucens prepupae in the diet. Reviews in Fish Biology and Fisheries 29: 465-486. https://doi. org/10.1007/s11160-019-09558-y

Udayangani, R.M.C., Dananjaya, S.H.S., Nikapitiya, C., Heo, G.-J., Lee, J. and De Zoysa, M., 2017. Metagenomics analysis of gut microbiota and immune modulation in zebrafish (Danio rerio) fed chitosan silver nanocomposites. Fish \& Shellfish Immunololy 66: 173-184. https://doi.org/10.1016/j.fsi.2017.05.018

Vargas-Abúndez, A.J., Randazzo, B., Foddai, M., Sanchini, L., Truzzi, C., Giorgini, E., Gasco, L. and Olivotto, I., 2019. Insect meal based diets for clownfish: biometric, histological, spectroscopic, biochemical and molecular implications. Aquaculture 498: 1-11. https://doi.org/10.1016/j.aquaculture.2018.08.018

Villasante, A., Ramírez, C., Catalán, N., Opazo, R., Dantagnan, P. and Romero, J., 2019. Effect of dietary carbohydrate-to-protein ratio on gut microbiota in Atlantic Salmon (Salmo salar). Animals 9: 89. https://doi.org/10.3390/ani9030089

Wang, G., Peng, K., Hu, J., Yi, C., Chen, X., Wu, H. and Huang, Y., 2019. Evaluation of defatted black soldier fly (Hermetia illucens L.) larvae meal as an alternative protein ingredient for juvenile Japanese seabass (Lateolabrax japonicus) diets. Aquaculture 507: 144-154. https://doi.org/10.1016/j.aquaculture.2019.04.023

Xiao, X., Jin, P., Zheng, L., Cai, M., Yu, Z. Yu, J. and Zhang, J., 2018. Effects of black soldier fly (Hermetia illucens) larvae meal protein as a fishmeal replacement on the growth and immune index of yellow catfish (Pelteobagrus fulvidraco). Aquaculture Research 49: 1569-1577. https://doi.org/10.1111/are.13611 
Zarantoniello, M., Bruni, L., Randazzo, B., Vargas, A., Gioacchini, G., Truzzi, C., Annibaldi, A., Riolo, P., Parisi, G., Cardinaletti, F., Tulli, F. and Olivotto, I., 2018. Partial dietary inclusion of Hermetia illucens (black soldier fly) full-fat prepupae in zebrafish feed: biometric, histological, biochemical, and molecular implications. Zebrafish 15: 519-532. https://doi.org/10.1089/zeb.2018.1596

Zarantoniello, M., Randazzo, B., Gioacchini, G., Truzzi, C., Giorgini, E., Riolo, P., Gioia, G., Bertolucci, C., Osimani, A., Cardinaletti, G., Lucon-Xiccato, T., Milanović, V., Annibaldi, A., Tulli, F., Notarstefano, V., Ruschioni, S., Clementi, F. and Olivotto, I., 2020. Zebrafish (Danio rerio) physiological and behavioural responses to insect-based diets: a multidisciplinary approach. Scientific Reports 10: 10648. https://doi.org/10.1038/s41598-020-67740-w
Zhang, H., Ran, C., Teame, T., Ding, Q., Hoseinifar, S.H., Xie, M., Zhang, Z., Yang, Y., Olsen, R.E., Gatlin, D.M., Ringø, E., Duan, M. and Zhou, Z., 2020. Research progress on gut health of farmers teleost fish: a viewpoint concerning the intestinal mucosal barrier and the impact of its damage. Reviews in Fish Biology and Fisheries 30: 569-586. https://doi.org/10.1007/s11160-020-09614-y 
